\title{
THE EFFECT OF SPORTS EVENTS ON THE MOTIVATION AND INTEREST OF REPEAT VISIT TOURISTS IN THE LAKE SIPIN TOURISM AREA, JAMBI CITY
}

\author{
Ugi Nugraha $^{1}$, Ely Yuliawan², Ceppy Pradana ${ }^{3}$ \\ Jambi University, Sport and Helath Education, Indonesia ${ }^{1,2,3}$ \\ ugi.nugraha@unja.ac.id
}

\begin{abstract}
This study aimed to analyze the effect of organizing sporting events on revisit intention mediated by the tourist motivation in the tourism area of Danau Sipin, Jambi City. The population in this study were tourists who visited the tourist area of Danau Sipin, Jambi City. The sample in this study was selected by accidental sampling method. This method was chosen because it was difficult to determine the visitor data for tourist attractions because it changes every day, so the samples were the visitor that the researcher met randomly in the tourist area of Danau Sipin, Jambi City. Data analysis in this study used the Partial Least Square (PLS) approach with the help of the WarpPLS 7.0 software. The results of this study indicated that organizing sporting events had a direct effect on motivation and revisit intention. The results of this study also indicated that the sporting events had an indirect effect on revisit intention which was mediated by tourist motivation
\end{abstract}

Keywords: revisit intention; sporting event; tourist motivation

\begin{tabular}{ll}
\hline Correspondence author: & Ugi Nugraha, Jambi University Sport and Helath Education, Indonesia. E- \\
& Mail: uginugraha29@yahoo.co.id
\end{tabular}

DOI http://dx.doi.org/10.31851/hon.v5i1.5953

\section{cc) () ()}

Jurnal Halaman Olahraga Nusantara licensed under a Creative Commons Attribution-ShareAlike 4.0 International License.

\section{INTRODUCTION}

Sports tourism is able to show its potential as something interesting, so that it can create a tourist attraction that can attract tourists to visit a tourist destination. Weed (2015) revealed that sports tourism is currently receiving great attention from the government, private sector, tourism industry, sports industry, academics and the wider community. This is very important because the development of sports tourism requires superior and reliable human resources in designing various kinds of sports activities so that they become tourist attractions that are worthy of sale because they have economic values and bring benefits to a country or region (Weed, 2015).

Esmaeli et al. (2016) revealed that the tourism industry is the largest and most diverse industry in the world. Tourism development requires the 


\section{OLATRAGA

involvement of community participation, and is directed at spurring increased global competitiveness, foreign exchange earnings, and improving the image of Indonesian tourism along with community-based tourism development. One form of community-based tourism development is sport tourism. Sport tourism is the activity of individuals and/or groups of people who participate actively or passively in sports competitions or recreation. Based on this, considering the huge potential of Indonesia's natural wealth, it is not impossible that this sport tourism can have potential for the regional and national economy by involving the community around the tourist area.

The Lake Sipin tourist area is an area that has recently been developed as a leading tourist destination in Jambi City. The lack of natural tourist destinations makes the Lake Sipin area have great potential for tourism development in the Jambi City. The unique factor of Lake Sipin is supported by the location of the lake which is in the middle of Jambi City, making it easier for people to access the area. The marketing aspect of tourist destinations is easier to do with the advantage of the geographical location of the area in the middle of the city so that transportation and accommodation support is readily available and very easy to reach around tourist destination areas. This advantage is also supported by the seriousness of the government in this case the Jambi Provincial and Jambi City Government to develop the area as a water tourism destination in Jambi City. In addition, the enthusiasm of the people in Jambi Province is one of the opportunities that will encourage the development of sports tourism in the Lake Sipin tourist area, Jambi City.

Organizing sports events is one of the efforts made by a tourist destination to increase the number of tourist visits (Nugraha et al., 2020). Meanwhile, Hemmonsbey and Tichaawa (2019) revealed that organizing sporting events generally presents an opportunity for the host destination to engage in branding practices which then enables the destination to increase the destination's brand awareness and communicate positive messages about the destination to the rest of 


\section{OLATRAGA

the world. Likewise, the opportunities for economic and social development are presented through the organization of sporting events. Organizing sports events has a positive impact on economic and social development opportunities around tourist destination areas (Nugraha et al., 2020).

Tourist motivation is a factor that influences tourist visits to a tourist destination. Tangkudung (2018) reveals that motivation is an encouragement or support that can make a person enthusiastic in carrying out an activity or activity. In relation to sports, Tangkudung (2017) reveals that a person's motivation to do sports activities, among others, is to get a challenging experience, have fun, get joy, and to release psychic tension. This is in line with the purpose of tourism travel, which is to travel for pleasure.

Tourism motivation is the main reason people get involved in tourism activities. Crandall in Hsiao-Ching (2017) defines tourism motivation based on individual needs for recreational recreation, which leads to individuals engaged in recreational activities and directs the activity towards a particular goals to meet the needs through recreational behavior. Meanwhile, according to Crompton and McKay in Hsiao-Ching (2017), "tourism motivation is conceptualized as a dynamic process of internal psychological factors (needs and desires) that produce a state of tension or disequilibrium within individuals". Baloglu and McCleary in Hsiao-Ching (2017) divide tourism motivation into factors such as relaxation and avoidance, stimulation and adventure, knowledge motivation, social motivation and prestige motivation.

Research on the effect of sporting events on revisit intention to a tourist destination was previously conducted by Dongfeng (2013) who revealed that organizing sports events can be useful in increasing tourist visits. Meanwhile, in the research of Imanda and Anandya (2020) it was revealed that the image of a sporting event did not directly affected the revisit intention, but had an indirect effect mediated by participant satisfaction. 


\section{OLATRAGA

Huang et al. (2018) conducted a study on the effect of motivation on the revisit intention. The results of this study indicated that the driving factors of sports tourism motivation have a significant effect on the revisit intention of tourists, but the influence of pull factors on the revisit intention of the tourists is not significant. In the common factors, the motivation of stimulus pursuit, social emotion, escape release, achievement satisfaction and true experience that they are all positive have a significant effect on the revisit intention of the tour. The probability of tourists' revisiting increases with the increase of the five motivational factors, while 'outside propaganda' and 'tourism attractions' has no significant impact on the revisit intention of the travel (Huang et al., 2018).

This study was to see how the influence of organizing sports events on the revisit intention to a tourist destination mediated by tourist motivation. Previous research by Nugraha et.al (2020) revealed that organizing sports events increased the number of tourist visits compared to normal days. He and Luo (2020) examined the effect of sport on tourist motivation which showed that the sport factor had the highest influence among the six motivational impact factors. Meanwhile in the research of Huang et al. (2018) revealed that sports motivation has a significant effect on revisit intention to a tourist destination.

The novelty of this research was that the researcher connected the holding of sports events with the revisit intention to a tourist destination through mediation of tourist motivation. Tourist attractions in the form of sports events held at a tourist destination can be an attraction for tourists to revisit a destination. The addition of the tourist motivation variable as a mediating variable for the effect of organizing sporting events on the revisit intention is a differentiator with previous studies. Sports events held at a tourist destination will increase the motivation of tourists to travel which then has an effect on revisit intention. Therefore, the researcher developed a research model using Structural Equation Modeling (SEM) analysis to see how the relationship between sporting events, tourist motivation and revisit intention to a tourist destination. 


\section{OLATRAGA

\section{METHOD}

This research was a quantitative research with causal explanatory relationship which aims to determine the pattern of causal relationship between the independent variable and the dependent variable. The use of the causal explanatory method was in accordance with the research objective, namely to test hypotheses that test the relationship and influence between the variables studied. The selection of this type of research was in accordance with the purpose of the study, namely to find out whether sports events affect the motivation and interest of tourists visiting the Lake Sipin tourist area, Jambi City.

The population in this study were tourists who visited the tourist area of Lake Sipin, Jambi City. The samples is part of the number and characteristics possessed by the population and is carefully selected from the population (Sugiyono, 2009). The sample in this study was selected by accidental sampling method. This method was chosen because it is difficult to determine visitor data for tourist attractions because it changes every day, so the samples were visitors who are randomly met by researchers in the Lake Sipin tourist area, Jambi City. According to Hair et. al. (2010) the number of samples is at least five times the number of indicators. The total number of indicators of the variables studied in this study were 16 , so the number of samples set were 5 x $16=80$ samples.

Researchers used questionnaires in collecting data in which there was a list of questions that have been prepared previously. Data was collected using a questionnaire with 5 (five) alternative answers consisting of answers Strongly Agree, Agree, Doubtful, Disagree, and Strongly Disagree.

Data analysis in this study used the Partial Least Square (PLS) approach with the help of WarpPLS 7.0 software. According to Ghozali (2011), PLS is an alternative approach that shifts from a covariance-based SEM approach to a variance-based approach. The advantage of using PLS is that PLS is a powerful analytical method because it does not assume the data must be of a certain scale and the number of samples is small (Ghozali, 2011). The estimation model 


\section{OLATRAGA

provides an empirical measure of the relationship between indicators and constructs (measurement model), and the relationship between constructs (structural model) (Kock, 2020). The steps for analyzing Partial Least Square (PLS) with the help of WarpPLS 7.0 software are as follows:

\section{Measurement Model}

The measurement model test is intended to determine the level of consistency and accuracy of the data collected from the use of research instruments. Measurement model is a measurement model to assess internal consistency (reliability), convergent validity, and discriminant validity (Hair et al., 2017).

\section{Convergent Validity}

Convergent validity testing was carried out using the loading factor value. According to Kock (2020), a measurement instrument has good convergent validity if the questions related to each latent variable can be understood by the respondent in the same way as intended by the question designer. In this case, two criteria are recommended as a basis for concluding that the measurement model has acceptable convergent validity, namely that the $\mathrm{P}$ value associated with the loading value is equal to or lower than 0.05 , and the factor loading value is equal to or greater than 0.5 (Kock, 2020).

Another measure to establish convergent validity at the construct level is average variance extracted (AVE). This criterion is defined as the average of the squared loading values of the indicators associated with the construct (ie, the number of squared loadings divided by the number of indicators). Therefore, AVE is equivalent to construct communality. Using the same logic as used with individual indicators, an AVE value of 0.50 or higher indicates that, on average, the construct explains more than half of the indicator's variance. In contrast, an AVE of less than 0.50 indicates that, on average, there is more variance in the item error than the variance explained by the construct (Hair et al., 2017). 


\section{OLATRAGA

2. Discriminant Validity

Hair et al. (2017) revealed that discriminant validity is the extent to which a construct is completely different from other constructs according to empirical standards. Cross-loadings are usually the first approach to assessing the discriminant validity of an indicator. In particular, the value of the outer loading indicator in the related construction must be greater than all the cross loading values in other constructions (Hair et al., 2017).

The Fornell-Larcker criterion is the second approach to assessing discriminant validity. This measurement is carried out using the ratio of the roots of the AVE with the correlation between latent variables. The construct AVE value should be higher than the correlation between latent variables (Kock, 2020).

3. Reliability Test

Kock (2020) revealed that reliability is a measure of the quality of a measuring instrument where the instrument itself is usually a set of question statements. A measurement instrument has good reliability if the questions related to each latent variable can be understood in the same way by different respondents. The reliability test in PLS can use two methods, namely Cronbach's alpha and Composite reliability. A construct is said to be reliable if the composite reliability and Cronbach's alpha values are equal to or greater than 0.7 (Kock, 2020).

\section{Structural Model}

Structural model testing is carried out to see the structural relationship between the latent variables studied (Kock, 2020). After the reliability and validity have been established, the main evaluation criteria for the PLS-SEM results are the coefficient of determination ( $\mathrm{R}^{2}$ value) and the size and significance of the path coefficient (Hair et al., 2017). Structural model testing in SEM-PLS analysis using WarpPLS is as follows: 


\section{OLATRAGA

1. Test the significance of the path coefficient

To test the hypothesis on the effect of exogenous variables on endogenous variables, it is done by comparing the results of the $\mathrm{p}$ value of the path coefficient with a significance level of $=0.05$. The test can be said to be very significant if the $\mathrm{p}$ value is less than or equal to 0.05 ( $\mathrm{p}$ value 0.05 ).

2. Determination coefficient $\left(\mathrm{R}^{2}\right)$

The coefficient of determination (R2) measures how much the model's ability to explain the variance of the dependent variable. Hair et al. (2017) revealed that the coefficient of determination is a measure of the combined ability of the exogenous latent variables to predict the construct of the endogenous variable, that is, the coefficient represents the amount of variance in the endogenous construct explained by all the exogenous constructs associated with it. $\mathrm{R}^{2}$ values range from 0 to 1 , with higher levels indicating higher levels of prediction accuracy.

\section{RESULT AND DISCUSSION}

\section{Result}

This study used the Partial Least Square analysis method on the Structural Equation Modeling (SEM). Data analysis was carried out with the help of WarpPLS 7.0 software. Data analysis using Partial Least Square was carried out in two steps, namely the outer model and inner model testing.

\section{Measurement (Outer) Model}

Outer model data analysis was conducted to test the indicator's ability to measure its latent variables. This analysis was conducted by looking at the validity and reliability of the indicators that was used in measuring the latent variables consisting of the variables of sporting events, tourist motivation, and revisit intention. 


\section{OLATRAGA

1. Convergent Validity

Convergent validity testing was carried out using the loading factor value. The results of convergent validity testing using the outer loading method can be seen in the following table:

Table 1. Loading Factor and Cross Loading

\begin{tabular}{ccccccc}
\hline Indicators & SE & TM & RI & Type $(\mathrm{a}$ & SE & P value \\
\hline SE1 & 0.690 & 0.034 & 0.216 & Reflect & 0.091 & $<0.001$ \\
SE2 & 0.674 & 0.218 & -0.130 & Reflect & 0.091 & $<0.001$ \\
SE3 & 0.753 & -0.121 & 0.000 & Reflect & 0.089 & $<0.001$ \\
SE4 & 0.717 & -0.069 & 0.114 & Reflect & 0.090 & $<0.001$ \\
SE5 & 0.736 & -0.110 & 0.036 & Reflect & 0.089 & $<0.001$ \\
SE6 & 0.801 & 0.060 & -0.023 & Reflect & 0.088 & $<0.001$ \\
SE7 & 0.831 & 0.004 & -0.182 & Reflect & 0.087 & $<0.001$ \\
TM1 & 0.238 & 0.715 & 0.037 & Reflect & 0.090 & $<0.001$ \\
TM2 & -0.035 & 0.727 & 0.065 & Reflect & 0.090 & $<0.001$ \\
TM3 & 0.171 & 0.802 & -0.105 & Reflect & 0.088 & $<0.001$ \\
TM4 & 0.006 & 0.781 & 0.031 & Reflect & 0.088 & $<0.001$ \\
TM5 & -0.340 & 0.843 & -0.016 & Reflect & 0.087 & $<0.001$ \\
RI1 & 0.041 & 0.097 & 0.782 & Reflect & 0.088 & $<0.001$ \\
RI2 & -0.210 & 0.078 & 0.872 & Reflect & 0.086 & $<0.001$ \\
RI3 & 0.245 & -0.023 & 0.733 & Reflect & 0.089 & $<0.001$ \\
RI4 & -0.038 & -0.172 & 0.739 & Reflect & 0.089 & $<0.001$ \\
\hline
\end{tabular}

Based on the table above, it can be seen that the loading factor values for all indicators for the variables of sporting events (SE), tourist motivation (TM), and revisit intention (RI) is greater than 0.5 with $\mathrm{p}$ value $<0.001$ which means that all indicators were declared valid and can be used as indicators to measure their respective latent variables.

The measurement of convergent validity, in addition to using the loading factor value, was also measured using the Average Variance Extracted (AVE). The measurement results can be seen in the following table:

Table 2. Average Variance Extracted Measurement Result

\begin{tabular}{lcc}
\hline & Latent Variables & Average Variance Extracted (AVE) \\
\hline SE & 0.555 \\
TM & 0.601 \\
RI & 0.614 \\
\hline
\end{tabular}

Based on the table above, it can be seen that the AVE values for the variables sporting events (SE), tourist motivation (TM) and revisit intention 


\section{OLATRAGA

(RI) were greater than 0.5 . This means that all indicators on each latent variable were able to measure well the latent variable.

\section{Discriminant Validity}

Measurement of discriminant validity was carried out using cross loading. The results of the measurement of discriminant validity using the cross loading method can be seen in table 3 below:

Table 3. Outer Loading and Cross loading Values

\begin{tabular}{cccc}
\hline Indicators & SE & TM & RI \\
\hline SE1 & 0.690 & 0.485 & 0.509 \\
SE2 & 0.674 & 0.496 & 0.328 \\
SE3 & 0.753 & 0.406 & 0.401 \\
SE4 & 0.717 & 0.456 & 0.447 \\
SE5 & 0.736 & 0.429 & 0.412 \\
SE6 & 0.801 & 0.538 & 0.458 \\
SE7 & 0.831 & 0.513 & 0.375 \\
TM1 & 0.569 & 0.715 & 0.441 \\
TM2 & 0.457 & 0.727 & 0.432 \\
TM3 & 0.582 & 0.802 & 0.425 \\
TM4 & 0.511 & 0.781 & 0.462 \\
TM5 & 0.366 & 0.843 & 0.394 \\
RI1 & 0.494 & 0.491 & 0.782 \\
RI2 & 0.385 & 0.459 & 0.872 \\
RI3 & 0.545 & 0.469 & 0.733 \\
RI4 & 0.344 & 0.314 & 0.739 \\
\hline
\end{tabular}

Based on table 3, it can be seen that the loading factor values of each indicator with its respective latent variables were greater than the value of its cross loading with other latent variables. There was no loading factor value from each indicator to each latent variable with a lower value than the cross loading value of each indicator with other latent variables. Thus, the test results using the cross loading value showed that all indicators meet the discriminant validity requirements.

Measurement of discriminant validity was also carried out using the ratio of the roots of the AVE with the correlation between latent variables. The construct AVE value should be higher than the correlation between latent variables (Kock, 2020). The results of discriminant validity testing using the Fornell-Larcker method were as follows: 


\section{OLATRAGA

Table 4. Correlation between Latent Variables with the AVE Root Values

\begin{tabular}{lccc}
\hline \multicolumn{1}{c}{ Latent Variables } & SE & TM & RI \\
\hline SE & 0.745 & 0.637 & 0.560 \\
TM & 0.637 & 0.775 & 0.553 \\
RI & 0.560 & 0.553 & 0.784 \\
\hline
\end{tabular}

The calculation results of WarpPLS 7.0 showed that the AVE root values of the same variable were higher than the AVE root values of different variables. This showed that the discriminant validity test criteria have been met. Thus the instrument used in this study had met all the provisions of the validity test.

\section{Reliability Test}

Reliability test was conducted to see the reliability of all indicators to measure a construct. A construct is said to be reliable if it has a high value of composite reliability and Cronbach's alpha. The recommended value for the composite reliability and cronbach alpha values is equal to or greater than 0.7 (Kock, 2020). The value of composite reliability and cronbach alpha can be seen in the following table:

Table 5. Composite Reliability and Cronbach's Alpha

\begin{tabular}{lcc}
\hline \multicolumn{1}{c}{ Latent Variables } & Composite Reliability & Cronbach's Alpha \\
\hline SE & 0,897 & 0,865 \\
TM & 0,882 & 0,833 \\
RI & 0,864 & 0,788 \\
\hline
\end{tabular}

Based on the table above, it can be seen that the composite reliability values for all variables were greater than 0.7 . This means that the measurement results on each construct were reliable and able to explain well each measured variables. The value of Cronbach's alpha on all variables were greater than 0.7 , which means that all constructs were reliable and the data from the measurement results of all indicators for measuring the latent variables were reliable. 


\section{OLATRAGA

\section{Inner Model Test}

This study was conducted to see the effect of organizing sporting events on the revisit intention mediated by tourist motivation as an intervening variable. Therefore, data analysis was carried out by looking at the influence of the variables of organizing sports events directly on the revisit intention and indirectly mediated by tourist motivation.

1. Test the significance of the path coefficient

Hypothesis testing was conducted to test the significance of the relationship between the latent variables of the study. The criteria used were by comparing the p-value of the results of hypothesis testing with a significance level of 0.05 . If the p-value $>0.05$, then the statistical hypothesis is accepted, thus exogenous variables have a significant effect on the endogenous variables.

Table 6. Direct Effect Path Coefficients and P Values

\begin{tabular}{cccl}
\hline Relationship & B & P Values & Decision \\
\hline SE $->$ TM & 0,562 & $<0.001$ & Significant \\
SE $>$ RI & 0.357 & $<0.001$ & Significant \\
TM $->$ RI & 0.333 & $<0.001$ & Significant \\
\hline
\end{tabular}

The results of the direct influence hypothesis testing can be seen in Table 6. Based on Table 6, the results of hypothesis testing can be formulated as follows:

a. The effect of sporting events on the motivation of tourists with a p-value was less than 0.001. This means that $\mathrm{H}_{0}$ was rejected and $\mathrm{Ha}$ was accepted. Thus, the sporting events had a significant effect on tourist motivation.

b. The effect of sporting events on the revisit intention with a p-value was less than 0.001. This means that $\mathrm{H}_{0}$ was accepted and $\mathrm{Ha}$ was rejected. Thus, the sporting events had a significant effect on the revisit intention.

c. The effect of tourist motivation on revisit intention with a p-value was less than 0.001 . This means that $\mathrm{H}_{0}$ was rejected and $\mathrm{Ha}$ was accepted. 
Thus, the motivation of tourists had a significant effect on the revisit intention.

The indirect effect testing of sporting events on the revisit intention mediated by the tourist motivation can be seen in the following table:

Table 7. Indirect Effect Path Coefficient and P Value

\begin{tabular}{cccc}
\hline Relationship & B & P Values & Decision \\
\hline SE -> TM -> RI & 0,217 & 0.002 & Significant \\
\hline
\end{tabular}

The indirect effect of sporting events on revisit intention that was mediated by tourist motivation with a p-value of 0.002 less than the significance level of 0.05 . This means that $\mathrm{H}_{0}$ was rejected and $\mathrm{Ha}$ was accepted. Thus, sporting events had a significant indirect effect on revisit intention mediated by tourist motivation.

\section{Determination Coefficient}

Hair et al. (2020) revealed that the determination coefficient is a measure of the combined ability of the exogenous latent variables to predict the construct of the endogenous variables. The determination coefficient can be seen in the following table:

Table 8. R-Square and Adjusted R Square

\begin{tabular}{ccc}
\hline Endogenous Variables & R Square & Adjusted R Square \\
\hline Tourist Motivation & 0,425 & 0,418 \\
Revisit Intention & 0,390 & 0,374 \\
\hline
\end{tabular}

Based on the table above, it can be explained that:

a. The value of R Square in the model with tourist motivation as an endogenous variable, namely the effect of sporting events on tourist motivation is 0.425 . This means that the sporting events was able to explain the tourist motivation by $0.425 \times 100 \%=42.5 \%$, where the remaining $57.5 \%$ were explained by other factors that were not included in the research variables.

b. The value of R Square with interest in revisiting as an endogenous variable, namely the influence of sporting events and tourist motivation on revisit intention was 0.390. This means that the organization of sporting events and 


\section{OLATRAGA

the motivation of tourists together can explain the revisit intention of $0.390 \mathrm{x}$ $100 \%=39.0 \%$, where the remaining $61.0 \%$ were explained by other factors that werre not included in the research variables.

\section{Discussion}

The results showed that there was a significant direct effect of organizing sporting events on tourist motivation. Thus, the increase in tourist motivation in the Lake Sipin tourist area of Jambi City was strongly influenced by an increase in the quality of organizing sports events. The better the organizing of sports events, the higher the motivation of tourists in the Lake Sipin tourist area, Jambi City. These results supported the results of He and Luo's (2020) research which stated that sport was a motivating factor for tourists' motivation. These results also supported the results of research by Nugraha et.al (2020) which revealed that organizing sports events increased the number of tourist visits compared to normal days.

The results of this study also showed that there was a significant direct effect of organizing sports events on the revisit intention in the Lake Sipin Tourism Area, Jambi City. These results supported the previous research conducted by Dongfeng (2013) which revealed that organizing sports events can be useful in increasing tourist visits.

This study also showed that tourist motivation has a direct effect on the revisit intention in the Lake Sipin Tourism Area, Jambi City. Thus, the higher the motivation of tourists will increase the revisit intention in the Lake Sipin Tourism Area, Jambi City. These results supported the results of research by Huang et al. (2018) which revealed that sports motivation has a significant effect on revisit intention to a tourist destination.

The results of this study also indicated that there was an indirect effect of organizing sporting events on the revisit intention to a tourist destination which was mediated by tourist motivation factors. This means that an increase in the 


\section{OLAHRAGA

organization of sporting events will increase the tourist motivation which in the next stage will have a positive effect on the revisit intention. The results of this study were in line with the research of Imanda and Anandya (2020) which revealed that the image of organizing sports events does not directly affect the revisit intention, but has an indirect effect mediated by participant satisfaction. The difference was, in this study, the effect of organizing sporting events on the interest in repeat visits was mediated by tourist motivation.

\section{CONCLUSION}

Based on the results of hypothesis testing and discussion, it can be concluded as follows:

1. Organizing sports events had an effect on tourist motivation, which means that improving the quality of organizing sports events could increase tourist motivation in the Lake Sipin tourist area, Jambi City.

2. The organization of sports events had a significant effect on the revisit intention, which means that improving the quality of organizing sports events could increase the revisit intention in the Lake Sipin tourist area, Jambi City.

3. Tourist motivation had an effect on revisit intention, which means that increasing tourist motivation could increase revisit intention in the Lake Sipin tourist area, Jambi City.

4. Organizing sports events had an effect on revisit intention mediated by tourist motivation, which means that improving the quality of organizing sports events had a significant impact on tourist motivation which then had an impact on increasing revisit intention in the Lake Sipin tourist area, Jambi City. 


\section{REFERENCES}

Dongfeng, L. (2013). Major sports events, destination image and intention to revisit from the foreign tourist's perspective. International Journal of Sports Marketing and Sponsorship, 14(3), 23-34. https://doi.org/10.1108/ijsms-1403-2013-b003

Esmaeili, N., Ganjuei, F. A., \& Tehran, F. T. (2016). Prioritizing Integrated Marketing Communication Tools in Sport Tourism in Iran Based on ACCA Model. International Journal of Sport Management, Recreation \& Tourism, 26, 54-66. https://doi.org/10.5199/ijsmart-1791-874X-26d

Ghozali, I. (2011). Structural Equation Modeling Metode Alternatif Dengan Partial Least Square (PLS) (Edisi 3). Semarang: Badan Penerbit Universitas Diponegoro.

Hair, J. F., Hult, G. T., Ringle, C., \& Sarstedt, M. (2016). A Primer on Partial Least Squares Structural Equation Modeling (PLS-SEM) - Joseph F. Hair, Jr., G. Tomas M. Hult, Christian Ringle, Marko Sarstedt. In Sage.

He, X., \& Luo, J. M. (2020). Relationship among Travel Motivation, Satisfaction and Revisit Intention of Skiers: A Case Study on the Tourists of Urumqi Silk Road Ski Resort. Administrative Sciences, 10(3), 56. https://doi.org/10.3390/admsci10030056

Hemmonsbey, J., \& Tichaawa, T. M. (2019). Strategic Planning of Sport Tourism Events on Destination Brands: Examining The Role of Homegrown Sport. GeoJournal of Tourism and Geosites, 26(3), 794-807. https://doi.org/10.30892/gtg.26310-398

Hsiao-ching, B. (2017). A Study of Sport Tourist's Participate Motivation, Travel Experience, Perceived Value and Behavioral Intention in Marine Sport Tourism. 17(5), 0-7.

Huang, Z., Kong, Y., \& Zhou, C. (2018). A study on relationship between sports tourism motivation and tourists' re-visiting intention: Based on Logistic model. 151(Emehss), 54-61. https://doi.org/10.2991/emehss-18.2018.13

Imanda, M. R., \& Anandya, D. (2020). Pengaruh Event Image, Destination Image, Past Experience Dan Participant Satisfaction Terhadap Revisit Intention Pada Marathon Event Di Indonesia. Jurnal Muara Ilmu Ekonomi Dan Bisnis, 4(2), 301. https://doi.org/10.24912/jmieb.v4i2.8187 
Indriantoro, N., \& Supomo, B. (2013). Metodologi Penelitian Bisnis Untuk. Akuntansi \& Manajemen. Yogyakarta: BPFE.

Kock, N. (2020). WarpPLS User Manual: Version 7.0. Texas: ScriptWarp Systems.

Nugraha, U., Asmawi, M., Humaid, H., Dlis, F., Ali, M., \& Iqroni, D. (2020). The Development of Sports Tourism in the Lake Sipin Region of Jambi City. Journal of Critical Reviews, 7(12), 608-612. https://doi.org/10.31838/jcr.07.12.109

Sugiyono. (2009). Metode Penelitian Pendekatan Kuantitatif, Kualitatif dan $R \&$ $D$. Bandung: Alfa Beta.

Tangkudung, J. (2018). SPORT PSYCHOMETRICS Dasar-dasar dan Instrumen Psikometr (Issue October). Jakarta: Rajawali Pers.

Tangkudung, J., \& Mylsidayu, A. (2017). Mental Training: Aspek-Aspek Psikologi dalam Olahraga. Bekasi: CAKRAWALA CENDEKIA.

Weed, M. (2015). After 20 years, what are the Big Questions for sports tourism research? Journal of Sport \& Tourism, 19(1), 1-4. https://doi.org/10.1080/14775085.2015.1032505 